\title{
錫/錫固相接合の界面強度に及ぼすギ酸の表面改質効果
}

\author{
小山真司 大屋一生*
}

群馬大学大学院工学研究科

J. Japan Inst. Metals, Vol. 73, No. 10 (2009), pp. 809-815

(C) 2009 The Japan Institute of Metals

\section{Effect of Formic Acid Surface Modification on Bond Strength of Solid-State Bonded Interface of Tin}

\author{
Shinji Koyama and Issei Oya* \\ Graduate School of Engineering, Gunma University, Kiryu 376-8515
}

The effect of formic acid surface modification on the bond strength of the solid-state bonded interface of tin has been investigated by SEM observations of the interfacial microstructures and fractured surfaces. Formic acid surface modification was carried out by boiling a tin surface (finished by electrolytic polishing) in formic acid for $750 \mathrm{~s}$. Solid-state bonding was carried out in a vacuum chamber at a bonding temperature $T_{\mathrm{j}}$ of $383-453 \mathrm{~K}$ and a bonding pressure $P_{\mathrm{j}}$ of $7 \mathrm{MPa}$ (bonding time $=1.8 \mathrm{ks}$ ). Because of surface modification, bonded joints were obtained at a bonding temperature that was $\sim 50 \mathrm{~K}$ lesser than the typical temperature required, and the bond strength was comparable to that of the base metal. When the joint strength was much lower than the base-metal strength, a number of fine inclusions were found to be distributed in the interfacial region. As the joint strength increased with bonding temperature, these inclusions were coarsened, and their distribution density decreased. The increase in joint strength with bonding temperature corresponded well with the observed change in the size and density of the inclusions.

(Received March 30, 2009; Accepted July 1, 2009)

Keywords: tin, solid-state bonding, bond strength, surface modification, formic acid

\section{1. 緒言}

固相接合法は，母材を溶融することなく，固相状態で顕著 な変形を加えずに加熱・加圧して接合する方法であり, 精密 組立接合が可能である1,2)。この点から，はんだ付に代わる 低温接合法として, 電子部品の基板上への接続法の一つとし て通用されることが期待される。しかしながら，はんだ自身 を溶融することなく, 固相状態で接合しようとした例はほと んぞ見られない，金属および合金の固相接合や，はんだ付に おいて, 接合面の密着化, 濡れ性, 毛細管現象などの接合過 程を支配する重要因子が，表面や界面の性状によって強い影 響を受けることは従来から良く知られてきた ${ }^{3,4)}$. 一部の貴 金属を除き，通常の大気中に置かれた金属は全て酸化皮膜で 覆われていると一般的に言われている5).この酸化皮膜が接 合現象に顕著な影響を及ぼす場合があり得ることは, 当然予 想されるところであるが, 接合過程に打ける酸化皮膜の挙動 を詳細に観察し，検討した議論は少ない6). そこで著者ら は，はんだ合金の主要成分元素として広範に用いられている 錫の酸化皮膜の接合界面での挙動を調べるために, 透過電子 顕微鏡によって直接的な観察を行ってきた. 前報において は, 接合表面を電解研磨仕上げした錫を固相接合し, 界面領 域の透過電子顕微鏡 $(\mathrm{TEM})$ の観察結果から, 接合中の酸化

\footnotetext{
* 群馬大学学生(Undergraduate Student, Gunma University)
}

皮膜の分布・形態の変化が，接合強さを支配する重要因子で あることを示した77.

そこで本報では，はんだ付におけるハロゲンフリーを目的 として, ギ酸を用いた場合の, 錫の固相接合強さに対する表 面改質効果を明らかにしようとした．このため，錫の接合表 面をギ酸中で煮沸することにより改質表面を形成後, その表 面同士を突き合せて固相接合し, 得られた継手の接合界面組 織や固相接合強さに対してどのような影響を及ぼすかを調 べ, 引張試験後の破断面の観察結果も併せて検討を加えた.

\section{2. 実 験 方 法}

実験に用いた接合用試験片は, 錫ブロック $(12 \mathrm{~mm} \times 15$ $\mathrm{mm} \times 15 \mathrm{~mm})$ に引張試験機への取り付け用として, 直方体 の銅ブロック $(10 \mathrm{~mm} \times 15 \mathrm{~mm} \times 15 \mathrm{~mm})$ を接合し, Fig. 1 に 示す形状に成形した後, 接合面となる一対の錫表面を, 加工 層の除去および平滑化を目的とした電解研磨により仕上げ た。電解液には $5 \mathrm{vol} \%$ 過塩素酸 $+10 \mathrm{vol} \%$ ブトキシエタ ノール $+85 \mathrm{vol} \%$ エタノール溶液を用い, 電解液中で温度 $273 \mathrm{~K}$, 電圧 $14 \mathrm{~V}$ の条件で, $120 \mathrm{~s}$ 間, 電解研磨を行った。 ギ酸による表面改質処理は，錫表面を沸騰したギ酸 (98\%) 中(約 $375 \mathrm{~K}$ ) で $0.3 \sim 1.2 \mathrm{ks}$ 間煮沸することにより行った.

以上により作製した接合用試験片の錫表面同士をつき合せ て, 真空炉中で接合時間を $1.8 \mathrm{ks}$, 接合温度を $393 \sim 453$ $\mathrm{K}$ ，接合圧力を $7 \mathrm{MPa}$ に設定して接合した。なお，ギ酸に 
より改質処理した表面の酸化あるいは吸湿による変化をでき るだけ抑えるため, 処理後 $180 \mathrm{~s}$ 間以内に接合用試験片を真 空炉中に設置するようにした。

得られた継手の錫/錫界面強度は, 引張試験によって評価 した. 引張試験片の形状は, 長さ, 幅および厚さがそれぞれ 約 $25 \mathrm{~mm} ， 12 \mathrm{~mm}$ 抢よび $3.5 \mathrm{~mm}$ で，接合面に垂直方向を 長手方向とし, この方向に引張試験した. 引張試験にはイン ストロン型試験機を用い, 变位速度を $0.017 \mathrm{~mm} / \mathrm{s}$ とした. 組織観察は, 接合界面に対し垂直方向の断面を走査電子顕微 鏡 $(\mathrm{SEM})$ により観察した。観察面は，1200 番のエメリ一紙 まで研磨した後, 電解研磨を行い, さらに $2 \mathrm{vol} \%$ 塩酸 +98 vol\%エタノール溶液で腐食して組織を現出させた.

\section{3. 実 験 結 果}

\section{1 錫/錫界面強度に対するギ酸の表面改質効果}

ギ酸の接合界面強度に及ぼす表面改質処理時間の影響を調

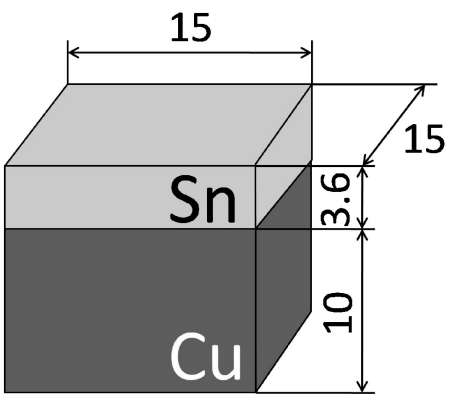

Fig. 1 Schematic illustration of specimen to be bonded (in $\mathrm{mm}$ ).

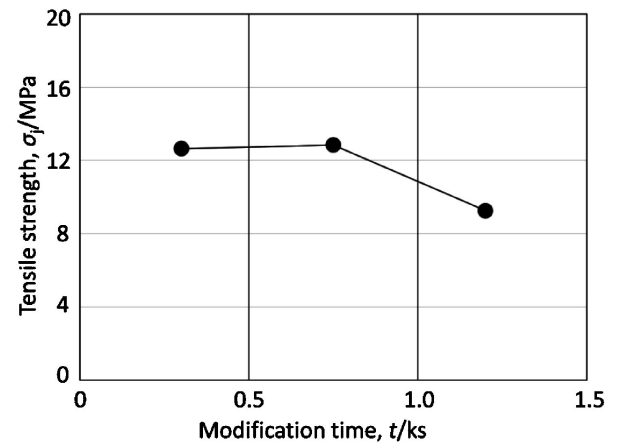

Fig. 2 Relation between tensile strength and modification time.
べるため，接合温度および接合時間をそれぞれ $443 \mathrm{~K}$ およ び $1.8 \mathrm{ks}$ 間で固定とし，処理時間を $0.3 \sim 1.2 \mathrm{ks}$ 間に変化さ せて接合し，得られた継手の接合界面特性を比較することに より処理時間の最適化を行った．処理時間と継手の引張強さ の関係を Fig. 2 に示し, 引張試験後の破断部外観写真を Fig. 3 に示す．処理時間と継手の引張強さの関係から (Fig. $2)$, 処理時間が $0.75 \mathrm{ks}$ の場合に最も高い引張強さを有する 継手が得られることが分った。 また，破断部の外観観察の結 果(Fig. 3), ぞの処理時間においても, かなりの断面収縮を 示した後に破断していた。しかしながら，処理時間 $0.75 \mathrm{ks}$ 間を除く 0.3 および $1.2 \mathrm{ks}$ 間の場合には界面破断した領域 が認められた。したがって，処理時間が 0.3 および $1.2 \mathrm{ks}$ 間の場合は, 界面強度の低い領域があるために, 引張強さが 低下したものと考えられる. 処理時間 0.3 および $1.2 \mathrm{ks}$ 間 の場合に抢いて界面破断した要因を調べるため，破断面を SEM により観察した。.との結果，処理時間 $0.3 \mathrm{ks}$ 間の場合 は, Fig. 4(a)に示すように，大きさ数 $\mu \mathrm{m}$ の微細な凹凸か らなる脆性的な破断形態が認められた. 一方，処理時間 1.2 ks 間の場合は，Fig. 4(b)に示すように，直径 $1 \mu \mathrm{m}$ 以下の 微細なくぼみが認められるものの, 延性的な破断形態を示す ことなく,なめらかな破断形態を示した。 また，改質表面性 状に及ぼす処理時間の影響を調べるため，処理時間を 0.3 お よび $0.75 \mathrm{ks}$ 間とした場合の処理表面を X 線回折(入射角度 を $5{ }^{\circ}$ に固定して $2 \theta$ スキャン)により同定した．その結果， Fig. 5 に示すように, 処理時間が $0.3 \mathrm{ks}$ 間の場合は, Snの 他に試料保持に用いたガラス板による Si と試料表面の電解 研磨あるいは改質処理中に生成したと考えられる $\mathrm{SnO}_{2}$ の回 折ピークが認められるが, $\mathrm{Sn}(\mathrm{HCOO})_{2}$ の回折ピークは認め られなかった．一方，処理時間が $0.75 \mathrm{ks}$ 間の場合は, $\mathrm{SnO}_{2}$ の回折ピークが認められなくなり, Sn の他に $\mathrm{Sn}(\mathrm{HCOO})_{2}$ の回折ピークが認められるようになった．したがって，処理
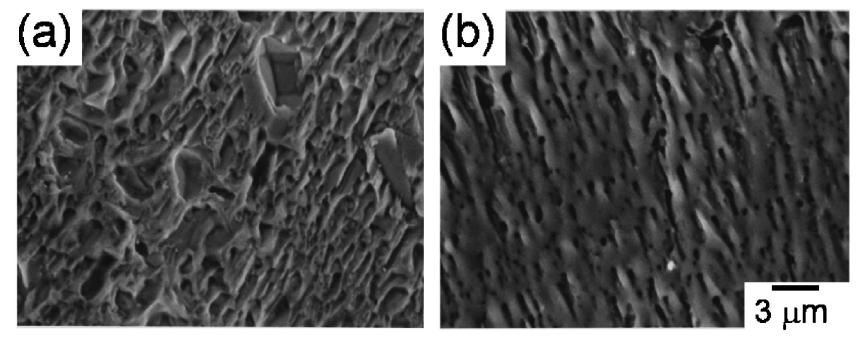

Fig. 4 SEM micrographs of fractured surfaces of joints after tensile test: (a) $t=0.3 \mathrm{ks}$ and (b) $t=1.2 \mathrm{ks}$.
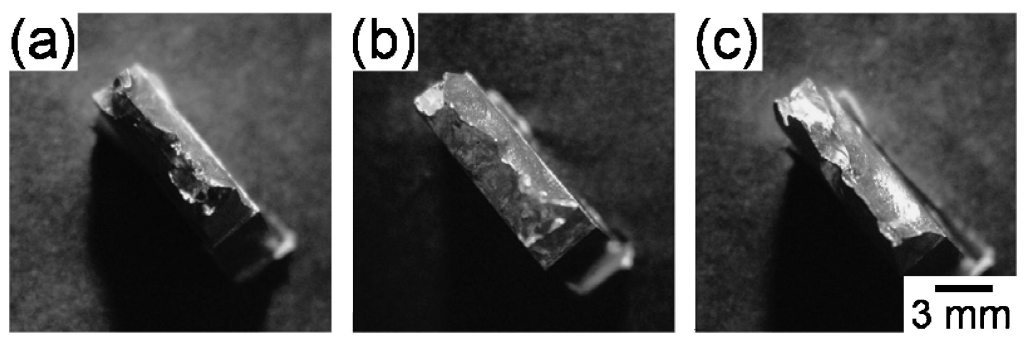

Fig. 3 Optical microscope images of fracture surfaces of joints after tensile test: (a) $t=0.3 \mathrm{ks}$, (b) $t=0.75 \mathrm{ks}$ and (c) $t=1.2 \mathrm{ks}$. 
時間が $0.3 \mathrm{ks}$ 間の場合は，酸化皮膜を含む接合表面が $\mathrm{Sn}$ $(\mathrm{HCOO})_{2}$ に十分置換されず，錫酸化物が残留したために， 脆性的な破断形態を示し，処理時間が $1.2 \mathrm{ks}$ 間の場合は， 接合表面に過剰の $\mathrm{Sn}(\mathrm{HCOO})_{2}$ が生成され，接合時間 $1.8 \mathrm{ks}$ では凝集せずに残存し，その内部で破断したため，なめらか な破断形態を示したものと推察される.これらの結果から， 最適処理時間は $0.75 \mathrm{ks}$ 間であると判断した.この最適処理 時間を用いて，ギ酸により錫の接合面を改質処理した場合， 継手の引張強さが接合温度とともにどのように变化するかを Fig. 6 に示す. 図中には比較のため, ギ酸による表面改質処 理を行わず，電解研磨仕上げしたままの接合表面を用いた場 合の測定結果も示した. Fig. 6 に示されるように, 表面改質 の有無に関わらず, 継手の引張強さは接合温度の上昇ととも に増加する傾向を示したが，電解研磨仕上げしたまま接合し た場合は 453〜 $463 \mathrm{~K}$ の範囲で大きな引張強さの上昇がみら れるのに対し，ギ酸により表面改質した場合は，393～403 $\mathrm{K}$ の範囲で急激な引張強さの上昇がみられた。したがって ギ酸により表面改質を行うと, 約 $60 \mathrm{~K}$ 低い接合温度から継 手の引張強さが増加することが分かった．破断面に拈いて， 界面破断した領域が全く認められず，断面収縮した後に母材 破断 (Fig. 3(b) 参照) する継手の得られる接合温度は, 電解 研磨仕上げしたまま接合した場合は $483 \mathrm{~K}$ 以上，ギ酸によ り表面改質を行った場合は $443 \mathrm{~K}$ 以上であり, 約 $40 \mathrm{~K}$ 低下

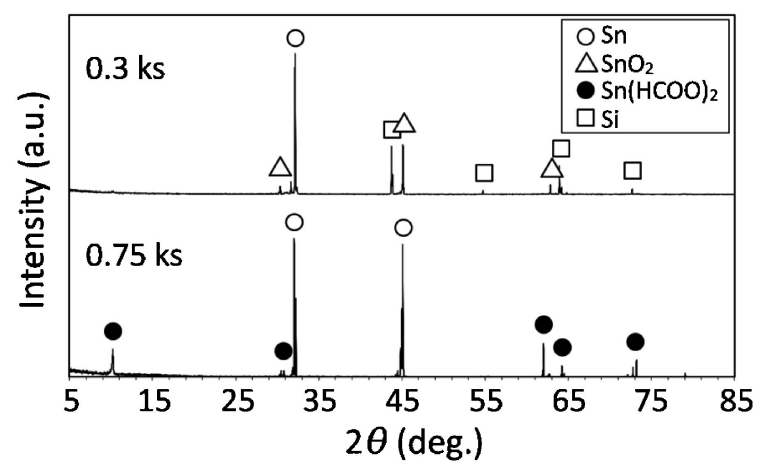

Fig. $5 \mathrm{X}$-ray diffraction patterns of the surfaces modificated by formic acid for $0.3 \mathrm{ks}$ and $0.75 \mathrm{ks}$.

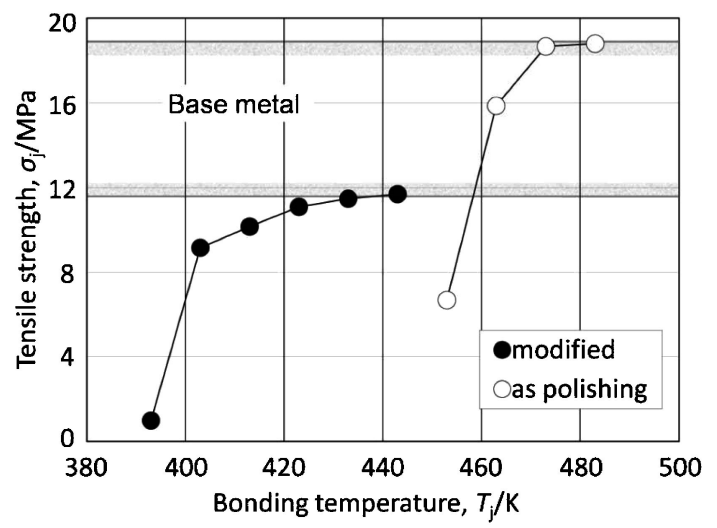

Fig. 6 Effect of the surface modification on the relation between tensile strength of joint and bonding temperature. The bonding pressure and time for all joints were $7 \mathrm{MPa}$ and $1.8 \mathrm{ks}$ respectively.
することが分かった。なお，それ以下の接合温度域ではいず れの場合も, 接続信頼性が著しく低い界面破断領域が認めら れた. また, 表面改質した場合と比較して, 電解研磨仕上げ したまま接合した場合は, 界面破断領域が認められるもの の, 高い引張強さを有する継手が得られることが分かった. 後述のように, 固相接合において, 銅ブロック間の錫部は塑 性変形し, ばりとして外周部に押し出された結果, 錫部の高 さが減少する. また塑性変形量は接合温度の上昇とともに増 加し, 引張試験において錫部は, 銅ブロックの塑性拘束をよ り強く受けるようになる.したがって, 表面改質を行った場 合に比べ電解研磨仕上げしたまま接合した場合は, 接合温度 が高く錫部の高さが低いために，銅ブロックによって錫部が 塑性拘束の影響を強く受けるようになり, 引張強さが増加し たものと考えられる。

接合温度を上昇させると, 銅ブロック間の錫部はより大き な塑性変形を生じて, 接合部外周にばりが形成され, その分 だけ接合面に対して垂直方向の高さが減少する。この減少量 を接合変形割合 $(D(\%))$ として, 継手の引張強さとの関係を 調べた結果をFig. 7 に示す。ここで接合変形割合とは, 次 式に示される值である.

$D=(1$ - 接合後の錫部高さ/接合前の錫部高さ $) \times 100 （ 1)$

Fig. 7 に示されるように, 継手の引張強さは接合変形割合 の増加とともに上昇し, 変形割合が $15 \%$ 以上にならないと 接合強さの顕著な上昇は生じないが， $20 \%$ 以上では急激に 継手の引張強さが上昇し, $45 \%$ 以上でほぼ母材並みの引張 強さを有する継手の得られることが分かった．なお，電解研 磨仕上げしたまま接合した場合に母材破断する継手を得るた めの接合変形割合は，65\%以上であり，表面改質を行うと 約 20\%低下することが分かった.

以上のような継手の引張強さに対する接合条件の影響が破 断形態にどのように反映されているかを調べるため, 破断面 をマクロ観察した．その結果，接合温度が $403 \mathrm{~K}$ 以下では，

Fig. 8(a) および Fig. 8(b)に示すように，ほとんど破断伸び を示さず脆性的に界面破断するのに対し，接合温度を $413 \mathrm{~K}$ 以上に上昇させると, Fig. 8(c) および Fig. 8(d)に示すよう に, 界面破断した領域が減少し, かなりの断面収縮を示した 後, 延性的に破断するようになった。

界面破断した領域を SEM により観察した結果を Fig. 9 お よび Fig. 10 に示す.

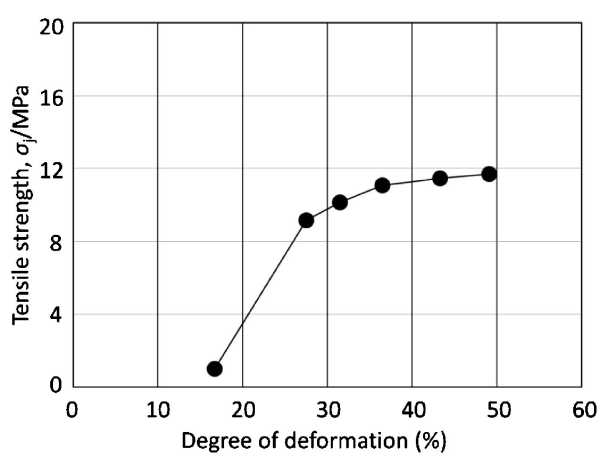

Fig. 7 Tensile strength vs. degree of deformation for joint bonded at various bonding temperatures. 

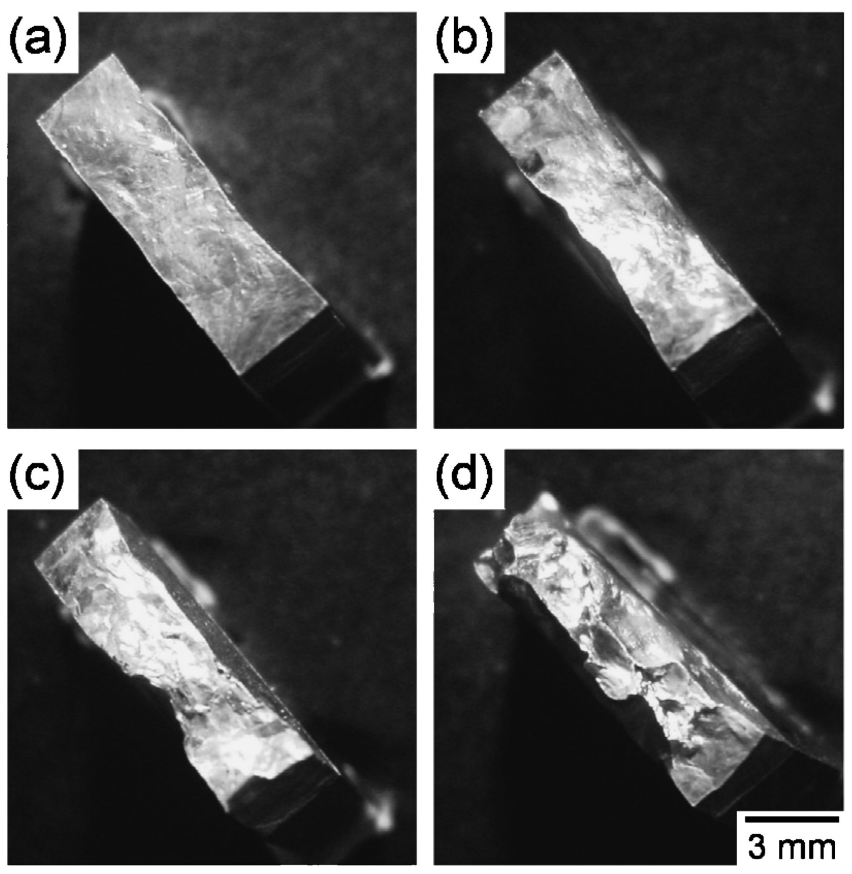

Fig. 8 Optical microscope images of fracture surfaces of joints after tensile test: (a) $T_{\mathrm{j}}=393 \mathrm{~K}$, (b) $T_{\mathrm{j}}=403 \mathrm{~K}$, (c) $T_{\mathrm{j}}=423 \mathrm{~K}$ and (d) $T_{\mathrm{j}}=433 \mathrm{~K}$.
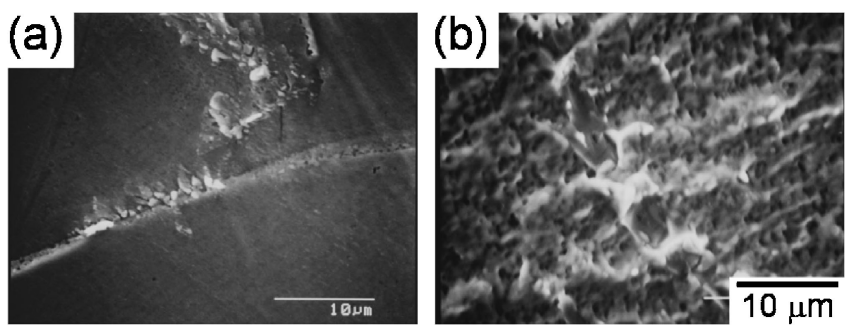

Fig. 9 SEM micrographs of fractured surfaces of joints after tensile test: (a) $T_{\mathrm{j}}=443 \mathrm{~K}$ and (b) $T_{\mathrm{j}}=463 \mathrm{~K}$.

ギ酸による表面改質処理を施さなかった場合, 接合温度が 453 K 以下では，Fig. 9(a)に示すように，破面形態はなめ らかで, 一部に起伏が認められるものの, 脆性的な破断形態 を示した。接合温度を $463 \mathrm{~K}$ に上昇させると, Fig. 9 (b)に 示すように，なめらかな破断形態を呈していた領域は減少 し, 微細なティアリッジあるいはディンプル状の延性的な破 断形態が認められるようになった. 引張試験後の破断面観察 の結果, 微細なティアリッジやディンプルが認められたの は，接合温度 $463 \mathrm{~K}$ 以上であり，母材並みの引張強さを有 する継手が得られた接合温度と一致した(Fig. 6).

ギ酸により表面改質処理を施した場合，接合温度が $393 \mathrm{~K}$ では, Fig. 10 (a)に示すように, 淡いコントラストを呈した 脆性的な破断面上に, 図中の白矢印で示すように, 直径数 $\mu \mathrm{m}$ の黑色を呈したいびつな形状の粒子が認められた. 接合 温度を $403 \mathrm{~K}$ に上昇させると, Fig. 10 (b)に示すように, 起 伏のある破断形態に変化し, 破断面上には大きさ $1 \mu \mathrm{m}$ 程度 の黒色を呈した球状の粒子 (図中の白矢印) と, 直径数 100 $\mathrm{nm}$ の微細な粒子が分散している様子(図中の白丸印) が認め られるようになった，接合温度を $423 \mathrm{~K}$ に上昇させると， Fig. 10 (c)に示すように, なめらかな破断形態を示した領域
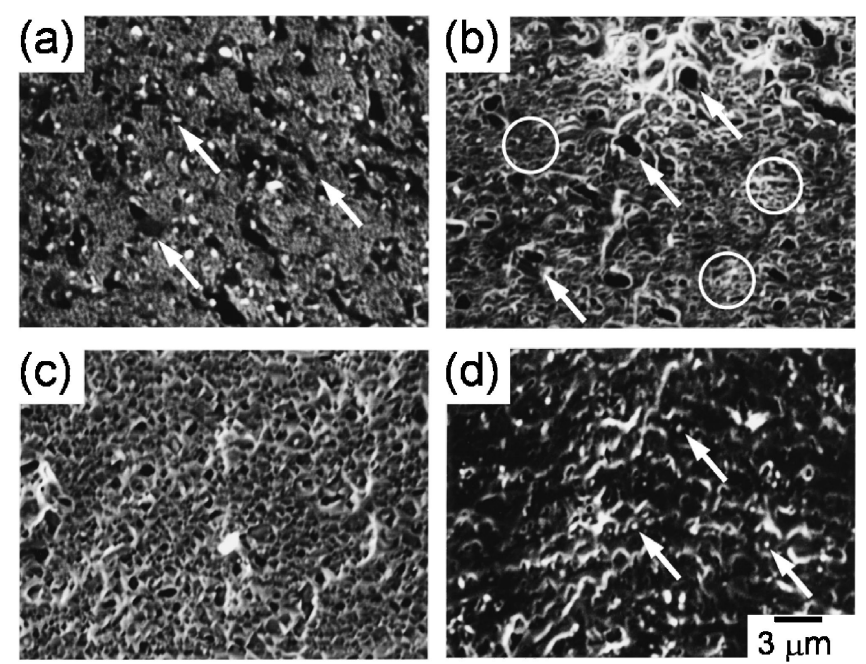

Fig. 10 SEM micrographs of fractured surfaces of joints after tensile test: (a) $T_{\mathrm{j}}=393 \mathrm{~K}$, (b) $T_{\mathrm{j}}=403 \mathrm{~K}$, (c) $T_{\mathrm{j}}=423 \mathrm{~K}$ and (d) $T_{\mathrm{j}}=433 \mathrm{~K}$

が減少し，微細なディンプル状の延性的な破断形態が認めら れるようになった．また，ディンプルの底には直径 $1 \mu \mathrm{m}$ 以 下の微細粒子が認められた. さらに接合温度を $433 \mathrm{~K}$ に上 昇させると, Fig. 8(d)に示すように, 破断はかなりの断面 収縮を示したのち生じるようになり, 母材破断と界面破断領 域が混在するが，界面破断した領域を観察すると Fig. 10 (d)に示すように, ディンプル径およびディンプルの底の 白色を呈した粒子 (図中の白矢印) が明瞭に粗大化する傾向が 認められた. 引張試験後の破断面観察の結果, 微細なディン プルが認められたのは, 接合温度 $423 \mathrm{~K}$ 以上であり，断面 収縮を示したのち破断した継手が得られた接合温度と一致し た. また, ギ酸により表面改質処理を施すと, 電解研磨仕上 げしたまま接合した場合に比べ, ディンプル状の延性的な破 断形態を示す接合温度が約 $40 \mathrm{~K}$ 低下することが分かった.

\section{2 ギ酸により表面改質処理した場合の錫/錫接合界面組織}

接合界面近傍の組織に及ぼすギ酸による表面改質効果につ いて検討するため, 接合界面近傍の組織を SEM により観察 した. 観察結果を Fig. 11 および Fig. 12 に示す。な拉接合 界面は，図中の黒矢印で示す領域である.

ギ酸による表面改質処理を施さなかった場合, 接合温度が $453 \mathrm{~K}$ 以下では, Fig. 11(a)に示すように, 直線状の接合線 が明瞭に認められた，接合温度を $463 \mathrm{~K}$ をで上昇させても 接合線は明瞭に残るが，Fig. 11(b)の白矢印に示すように， 接合界面の結晶粒界が接合線から最大で $2 \mu \mathrm{m}$ 程度移動して いる領域が一部に認められるようになった．接合温度 $463 \mathrm{~K}$ に抢ける錫の自己拡散係数 $\left(D=6.2 \times 10^{-16} \mathrm{~m}^{2} / \mathrm{s}\right)$ を用い て, 次式 $(2)$ により粒界の移動距離を見積もった.

$$
d=\sqrt{2 D t}
$$

ここで， $d$ は粒界の移動距離 $(\mathrm{m}), t$ は接合時間 $(\mathrm{s})$ である。 接合時間 $1.8 \mathrm{ks}$ を用いて計算すると $d$ は $1.5 \mu \mathrm{m}$ となり, 実 測值とほぼ一致することが分かった．したがってこの接合界 面に打ける粒界移動は, 錫の自己拡散によるものであると考 えられる。 


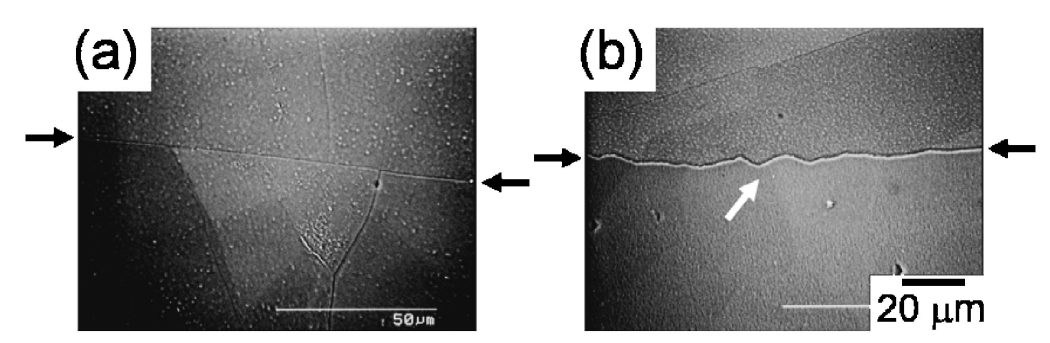

Fig. 11 SEM micrographs of bond interfaces: (a) $T_{\mathrm{j}}=443 \mathrm{~K}$ and (b) $T_{\mathrm{j}}=463 \mathrm{~K}$.
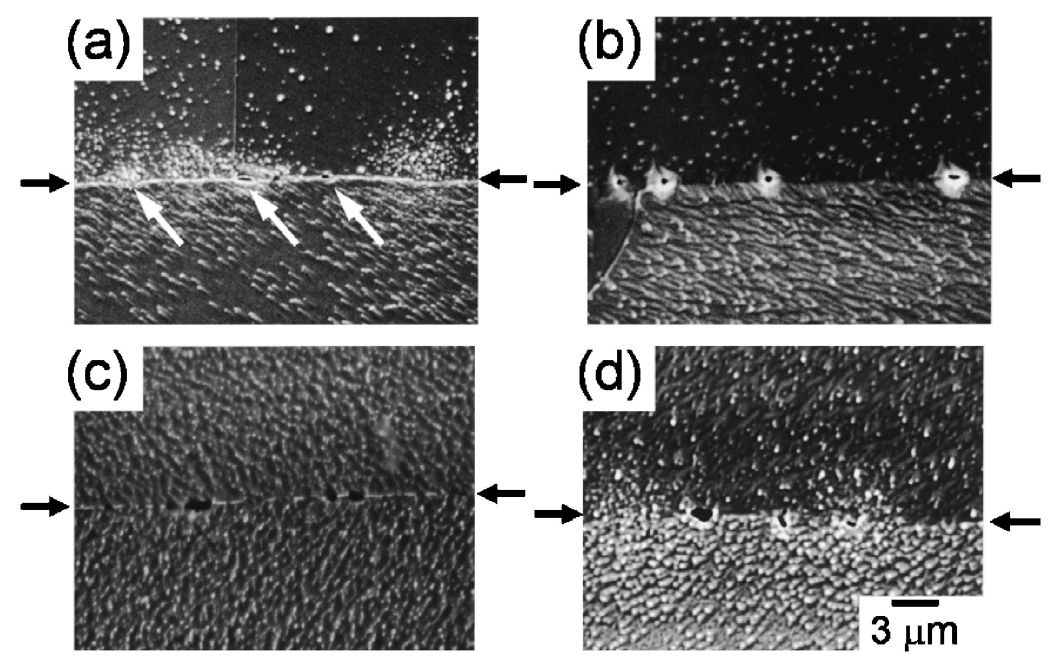

Fig. 12 SEM micrographs of bond interfaces: (a) $T_{\mathrm{j}}=393 \mathrm{~K}$, (b) $T_{\mathrm{j}}=403 \mathrm{~K}$, (c) $T_{\mathrm{j}}=423 \mathrm{~K}$ and (d) $T_{\mathrm{j}}=433 \mathrm{~K}$.

ギ酸により表面改質処理を施した場合，接合温度を 393〜 $433 \mathrm{~K}$ に変化させると，接合温度 $393 \mathrm{~K}$ では, Fig. 12 (a)に 示すように，接合界面に厚さ数 $100 \mathrm{~nm}$ の白色を呈した帯状 の介在物が連続的に認められ，幅 $1 \mu \mathrm{m}$ 程度の偏平な形状を した介在物も認められた (図中の白矢印)。これらの介在物 は, 大きさ, 形状および分布密度から判断して, 帯状の介在 物は破断面上の淡いコントラストを呈した脆性的な破断領域 に相当し，偏平な形状をした介在物は破断面上の黒色を呈し たいびつな形状の粒子の断面組織に相当すると考えられる. したがって, 接合界面に高密度の介在物が分布している場合 は，高い引張強さを示さず，介在物内部あるいは錫母相と介 在物間で脆性的に破断することが分かった．接合温度を 403 K に上昇させると, Fig. 12 (b) に示すように，接合線上に は, 球状の介在物が認められた。この介在物は, 形状抢よび 分布密度から判断して, 破断面上の黒色を呈した球状粒子で あると考えられる。一方，接合温度 $393 \mathrm{~K}$ で認められた白 色の帯状介在物は認められなくなり, 破断面に抢いて淡いコ ントラストを呈した脆性的な破断領域が認められなくなった 接合温度と一致した。よって，接合温度を $393 \mathrm{~K}$ から 403 $\mathrm{K}$ に上昇させた場合に, 継手の引張強さが大きく上昇した のは, 白色の帯状介在物が分断され, 微細な粒子状に分散し たためであると推察される.さらに接合温度を $423 \mathrm{~K}$ 以上 に上昇させると，Fig. 12 (c) 抢よび Fig. 12 (d)に示すよう に, 接合温度の上昇とともに介在物の大きさが増加し, 分布 密度がわずかに減少する傾向が認められた。 また, 結晶粒界 が接合界面を脱して移動した結果，SEMの観察視野内では

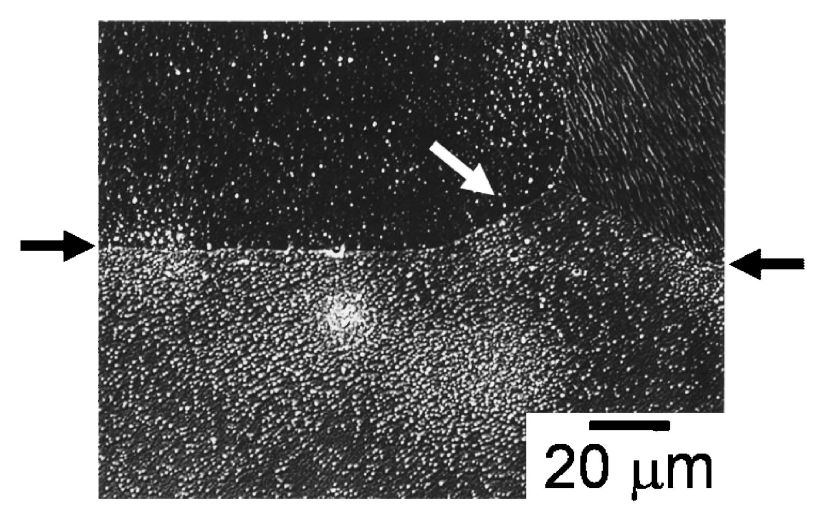

Fig. 13 SEM micrograph of bond interface bonded at $423 \mathrm{~K}$.

一部の領域で粒界が認められなくなり，接合線が不明瞭にな る傾向を示した。接合温度が $423 \mathrm{~K}$ の場合の, 結晶粒界が 接合界面を脱して移動した領域を SEM により観察した結果 をFig. 13 に示す. Fig. 13 に示す接合界面領域では, 結晶 粒界が接合線から約 $20 \mu \mathrm{m}$ 移動しているのが分かる. 接合 温度 $423 \mathrm{~K}$ に打ける錫の自己拡散係数 $\left(D=4.5 \times 10^{-17} \mathrm{~m}^{2}\right)$ s)を用いて, 式 ( 2 )により粒界の移動距離を見積もった結果, $0.4 \mu \mathrm{m}$ となり, 実測值とは大きく異なる.これは, 粒界移 動が観察された領域が, 接合界面と母材の粒界とが交わる粒 界三重点であり, 粒界移動の駆動力として粒界エネルギーあ るいは表面エネルギーが作用したためであると考えられる.

以上の観察結果から，接合線を横切って粒界の移動し始め 
る接合温度が，ギ酸により表面改質した場合は $423 \mathrm{~K}$ とな り，ギ酸による表面改質処理を施さなかった場合と比べおお よそ $40 \mathrm{~K}$ 低下することが分かった. 前報7にに抢いて，接合 線を横切って粒界が移動できるのは，ピン止め効果を有する 接合界面近傍の介在物の凝集 - 粗大化による分布密度の減少 に伴うものであることを示唆した。 したがって，電解研磨仕 上げしたまま接合した場合に比べ，ギ酸により表面改質した 場合は，接合界面近傍の介在物がかなり低い接合温度から凝 集し，分布密度が減少していると考えられる.

\section{4. 考察}

大気に曝された錫の表面は，ただちに酸化皮膜で覆われる 々一般的に考えられている. 我々の研究においても，ギ酸に よる表面改質処理を施さなかった場合，接合温度が $443 \mathrm{~K}$ では，Fig. 14(a)の矢印間に示すように，接合界面近傍には 厚さ $10 \mathrm{~nm}$ 程度の連続的な膜状介在物が認められた。この 膜状介在物を含む領域から得られた $\mathrm{SAD}$ パターンの 1 例が Fig. 14(b)である.これは正方晶の Snの他，斜方晶の $\mathrm{SnO}$ の回折図形と指数付けされた (Fig. $14(\mathrm{~d}))$. SnO の 112 反 射の回折線を用いて撮影した暗視野像を Fig. 14 (c) に示す. したがって接合温度 $443 \mathrm{~K}$ で接合された継手は，連続的な 酸化皮膜が接合界面に存在するために，接合強さが低く，ま た延性破面領域をほとんど示すことなく接合界面で脆性的に 破断したのであろうと考えられる(Fig. 9(a)).

これらの酸化皮膜及び錫母相は, ギ酸と長時間煮沸するこ とによりギ酸錫 (II)を生成すると言われている8)。これらの 生成反応を式 $(3) \sim(5)$ に示す.

$$
\begin{aligned}
& \mathrm{Sn}+2 \mathrm{HCOOH} \longrightarrow \mathrm{Sn}(\mathrm{HCOO})_{2}+\mathrm{H}_{2} \uparrow \\
& \mathrm{SnO}+2 \mathrm{HCOOH} \longrightarrow \mathrm{Sn}(\mathrm{HCOO})_{2}+\mathrm{H}_{2} \mathrm{O} \\
& \mathrm{SnO}_{2}+2 \mathrm{HCOOH} \longrightarrow \mathrm{Sn}(\mathrm{HCOO})_{2}+\mathrm{H}_{2} \uparrow+\mathrm{O}_{2} \uparrow
\end{aligned}
$$

すなわち，ギ酸による改質操作によって，少なくとも接合 表面近傍には $\mathrm{Sn}(\mathrm{HCOO})_{2}$ からなるギ酸錫(II)が生成してい
るものと考えられ, 改質処理後の錫表面における X 線回折 測定結果 (Fig. 5)は, 式 (3)〜 ( 5 ) からなる改質作用を裏付 けている。

表面酸化皮膜を含む錫の，ギ酸による改質作用を調べるた め, 厚さ $7 \mu \mathrm{m}$ の錫䈃(約 $0.014 \mathrm{~g}$ ) をギ酸中で $0.75 \mathrm{ks}$ 間(本 研究で用いた処理時間)煮沸し, 直ちに示差走査熱量測定を 行った. 測定結果を Fig. 15 に示す. 測定結果より, 本研究 で用いた接合温度範囲近傍には，Fig. 15 に示すように， 425〜 493 K に発熱ピークが認められた。よって，ギ酸によ り改質操作を行った接合面において，接合温度 $423 \mathrm{~K}$ 近傍 では何らかの前駆的な反応が生じたものと考えられる．実 際, 脆性的な破断形態からディンプル状の延性的な破断形態 に変化した接合温度域とほぼ一致している。またギ酸錫 $($ II $)$ は， $453 \mathrm{~K}$ 以上に加熱すると，酸化錫，炭酸ガス，ホルムア ルデヒドなどに分解すると言われている ${ }^{9)}$ 。したがって，測 定温度 $453 \mathrm{~K}$ 近傍における発熱量の急激な上昇は, ギ酸錫 (II)の分解に伴う発熱反応であると推察される.

以上のことから，接合温度 $423 \mathrm{~K}$ 近傍に打いて，脆性的 な破断形態から延性的な破断形態に変化し，継手の引張強さ

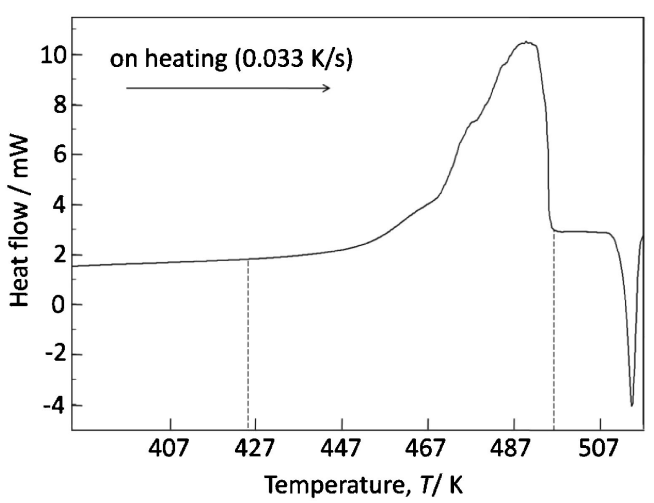

Fig. 15 DSC curves of modified tin by formic acid. The modifying time was $0.75 \mathrm{ks}$.

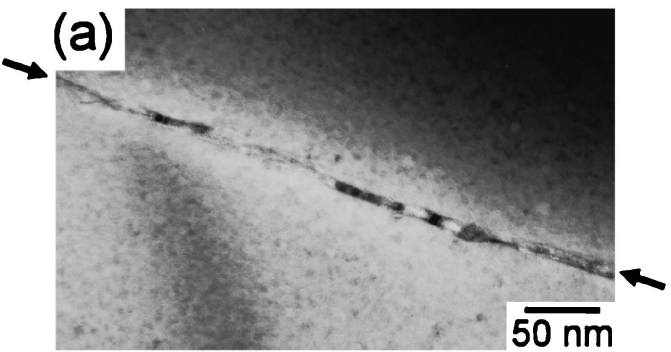

(c)

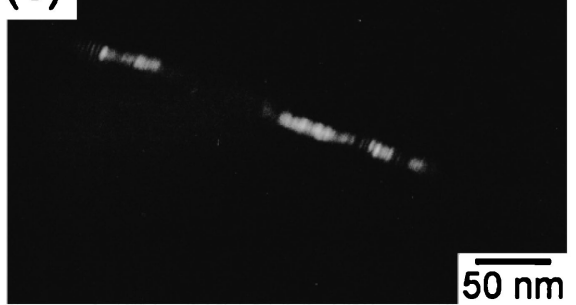

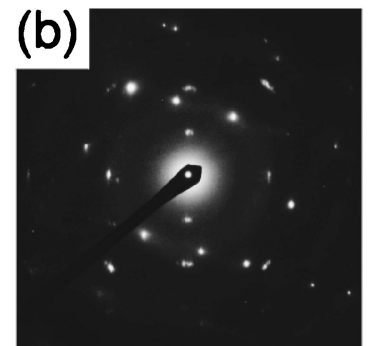

(d)

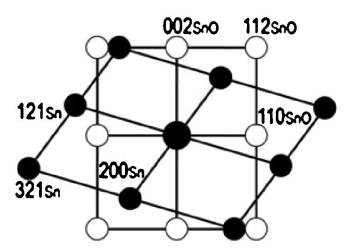

Fig. 14 TEM micrographs of oxide film of $\mathrm{SnO}$ at a joint interface $T_{\mathrm{j}}=443 \mathrm{~K}$ ): (a) bright field image, (b) SAD pattern, (c) dark field image and (d) key diagram. 
が向上したのは，ギ酸による改質操作により接合表面にギ酸 錫（II）が生成し，この生成物が $425 \mathrm{~K}$ 近傍で反応を開始し た結果, 錫の酸化物に比べて, より低い接合温度で凝集・粗 大化し, 分布密度が減少して, 真実接合面積が増加したため であると推察される。

\section{5. 結言}

本研究では, 錫の固相接合において, 接合強さに及ぼす接 合表面のギ酸による表面改質の影響を調べ検討を加えた，得 られた結果は以下のように要約される.

（1）接合表面をギ酸により表面改質した場合，接合温度 $403 \mathrm{~K}$ 付近から引張強さが上昇し， $433 \mathrm{~K}$ でほぼ母材強度と 同等に達した.

(2) 継手の引張試験後の破面にはディンプル状の形態が観 察され，ディンプルの底には介在物が認められた。これらの 介在物は接合温度の上昇とともに粗大化と, 分布密度の減少 を生じ，これに伴いディンプルが深く大きく変化した．

（3）上記の(1), (2)の結果は, 改質処理を施さない場合の接 合界面における酸化物と比べてギ酸錫 (II)は，いずれもより 低い接合温度から凝集・粗大化し得ることを示唆している.
凝集・粗大化した粒子の周辺では，介在物の分布は減少して おり，このため真実接合面積が増加し，これに伴いより低い 接合温度から継手の引張強さが上昇したものと考えられる.

なお, 本研究の一部は財団法人群馬大学科学技術振興会研 究費助成を受けて遂行した．ここに感謝の意を表す。

文献

1) T. Enjyo: Journal of JWS 50(1981) 335-352.

2) T. Enjyo: J. Japan Inst. Metals 26(1987) 706-711.

3) R. F. Tylecote: The Solid Phase Welding of Metals, (Edward Arnold, London, 1968) p. 203

4) T. Hashimoto and I. Okamoto: Koso Yosetsu Roudzuke, (Sampo Shuppan, 1979) pp. 96-97.

5) N. Igata, M. Douyama and H. Okamura: Zairyokagaku1 -Zairyo no Bishitekikozo-, (Baifukan, 1994) pp. 163-165.

6) K. Kotani, K. Ikeuchi and F. Matsuda: Quarterly Journal of JWS 14(1996) 551-562.

7) S. Koyama, M. Takahashi and K. Ikeuchi: Mater. Trans. 45 (2004) 300-302.

8) S. Yuji and K. Kimura: Muki Kagaku Zensyo VII-1-1 Suzu, (Maruzen, 1963) p. 360.

9) K. Nakahara: Muki Kagoubutsu·Sakutai Ziten, (Koudansha, 1997) p. 153. 